\title{
ВИЗНАЧЕННЯ ДОСТУПНОСТІ АНТИДЕПРЕСАНТІВ ДЛЯ ФАРМАКОТЕРАПІЇ ПСИХІЧНИХ РОЗЛАДІВ У ПОСТРАЖДАЛИХ ОСІБ (ЕКСПЕРИМЕНТАЛЬНЕ ДОСЛІДЖЕННЯ)
}

\section{DETERMINING THE AVAILABILITY OF ANTIDEPRESSANTS FOR THE PHARMACOTHERAPY OF MENTAL DISORDERS AMONG VICTIMS (EXPERIMENTAL STUDY)}

Андрій Гудзенко (Andrii Gudzenko) ${ }^{1}$

1 Харківська медична академія післядипломної освіти, Харків, Україна (Kharkiv Medical Academy of Postgraduate Education, Kharkiv, Ukraine)

*Corresponding author: Andrii Gudzenko, affiliated to Kharkiv Medical Academy of Postgraduate Education, Kharkiv, Ukraine
Received: June 28, 2021

Published: October 19, 2021
Abstract. The availability of drugs for international nonproprietary names "Sertraline", "Tianeptin", "Amitriptyline" using an integrated approach was studied. It is substantiated that drugs under international nonproprietary name "Sertraline" are the most accessible for medical staff and affected patients. Particularities of clinical and pharmacological, classification and legal, nomenclature and legal groups of drugs according to international nonproprietary name "Sertraline" were determined. It is noted that the use of drugs under the international nonproprietary name "Sertraline" will comply with the principles of socially oriented pharmacotherapy of mental disorders for the affected contingents of patients in a special period in Ukraine.

Keywords: mental disorders, depression, antidepressants, affected contingents.

Вступ. У попередніх дослідженнях було зазначено, що за минулі десятиліття судово-фармацевтичні дослідження неконтрольованого обігу та нераціонального вживання психоактивних речовин (ПАР) різних клінікофармакологічних груп, поширення адиктивних розладів здоров'я (АРЗ), зростання правопорушень і злочинів у стані алкогольного або наркотичного сп'яніння перетворилися на самостійний напрямок у фармації зі своєю методологією, науковими програмами і школами, перспективними напрямками дослідницької діяльності та сформованими міждисциплінарними зв'язками. Активно розробляються медикаментозні, фармакотерапевтичні, профілактичні та попереджувальні напрямки судової фармації, сформульована концепція причинно-наслідкових зв'язків при виникненні, формуванні та розповсюдженні АРЗ від ПАР різних клініко-фармакологічних груп, визначені основні організаційно-правові та судово-фармацевтичні підходи до розв'язання проблеми психічних та неврологічних хвороб, алкогольної та наркотичної залежностей [1-5]. 
Втім, незважаючи на досягнуті успіхи, питання судової фармації в рамках медичного та фармацевтичного права в суспільній свідомості набуває усе більшої науково-практичної актуальності і соціальної значущості тому, що триває загострення ситуації з обігом та зловживанням ПАР різних клінікофармакологічних груп у всіх без винятку регіонах нашої країни. На підтвердження останнього свідчать численні організаційно-правові, медикосоціальні, судово-фармацевтичні, соціологічні і криміналістичні дослідження. Наприклад, зловживання ПАР у вигляді алкогольних напоїв (АН) на регіональному рівні свідчить про зростання випадків алкогольної інтоксикації у підлітків, що згубно впливає на подальшу народжуваність та працездатність у цій області [6-10].

3 іншого боку було доведено, що постраждалі особи в умовах воєнних дій, самі потребують відповідної медико-фармацевтичної допомоги тому, що страждають на психічні розлади (депресія, алкогольна залежність внаслідок зловживання алкогольними напоями різної міцності (пиво, вино, горілка, тощо). У структурі алкогольної залежності лікарі-наркологи фіксують депресивні та поведінкові розлади, для фармакотерапії яких використовуються антидепресанти [11-14].

В умовах поширення коронавірусної пандемії зростає роль визначення доступності сучасних, ефективних i безпечних андидепресантів у фармакотерапії психічних розладів у постраждалих контингентів пацієнтів [1517].

Мета роботи. Опрацювання доступності для медперсоналу та пацієнтів клініко-фармакологічної групи антидепресантів для фармакотерапії депресивних розладів у постраждалих осіб з використанням комплексного підходу шляхом клініко-фармакологічного, нормативно-правового, документального, маркетингового, соціологічного, статистичного аналізу.

Матеріали та методи. Дослідження доступності антидепресантів проводилося на базі кафедр медичного та фармацевтичного права, загальної і клінічної фармації, наркології Харківської медичної академії післядипломної освіти упродовж 2018-2020 років. Матеріалом імперативного вивчення стали діючі законодавчі, нормативно-правові та інструктивно-методичні документи; Інтернет-ресурси (сайти zakon.rada.gov.ua, zakon2.rada.gov.ua, most-dnepr.info, tlaw.nlu.edu.ua, bsphs.org,rr.bsu.edu.ru), джерела наукової літератури, анкети анонімного опитування слухачів кафедри (лікарі психіатри, наркологи, сімейні лікарі, провізори). В анкети було включено питання щодо використання лікарських засобів (ЛЗ) для фармакотерапії депресивних розладів у пацієнтів (постраждалі особи та їх близькі родичі). Всього було анкетовано 57 лікарів та 130 провізорів. Застосовано методи організаційно-правового, клінікофармакологічного, маркетингового, соціологічного (анонімне опитування), судово-фармацевтичного, нормативно-правового, документального, порівняльного, статистичного та графічного аналізу. Статистичну обробку проведено за допомогою програми Statistica 6.0 [18-24]. 
Результати дослідження та їх обговорення. Серед антидепресантів останнього покоління у фармакотерапії психічних розладів зарекомендував себе Л3 серліфт. Міжнародна непатентована назва (МНH) активної речовини сертралін. Раніше була запропонована схема фармакотерапії депресивних розладів при АЗ із включенням ЛЗ за МНH «Сертралін» (Рис. 1). Схема фармакотерапії використовувалася у лікувальному процесі на базі Харківського обласного наркологічного диспансеру під керівництвом проф. Сосіна І.К. для пацієнтів із депресивними розладами при алкогольній залежності (АЗ). Призначення ЛЗ за МНН «Сертралін» відбувалося при виконанні таких умов: після проведення детоксикації та купірування абстинентного синдрому; термін утримання від вживання алкогольних напоїв повинен був дорівнювати не менше 7-10 днів; пацієнт повинен мати психотерапевтичну установку на позбавлення від депресивних розладів та АЗ; врахування можливого розвитку побічних ефектів (клінічні ознаки тривоги, депресії, підвищена дратівливість, зниження лібідо, тощо) $[25,26]$.

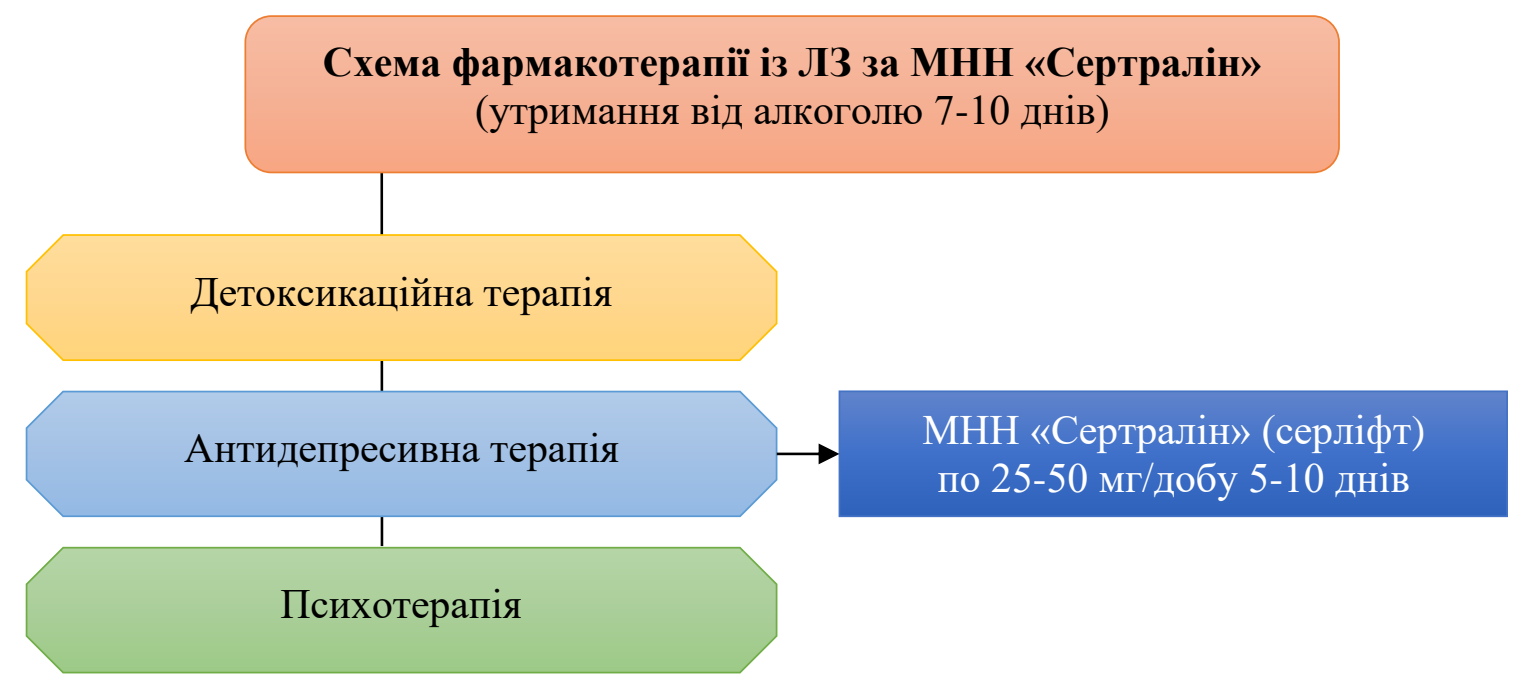

Рис. 1. Схема фармакотерапії депресивних розладів із включенням ЛЗ за МНН «Сертралін» (серліфт).

Переваги розробленої схеми фармакотерапії депресивних розладів при АЗ із включенням серліфту було вивчено в порівнянні із антидепресантами за МНH Аамітриптилін» $\mathrm{i}$ «Тіанептин» [31], що приведено у табл. 1.

Таблиця 1. Переваги розробленої схеми фармакотерапії депресивних розладів при АЗ.

\begin{tabular}{|l|c|c|c|}
\hline $\begin{array}{c}\text { № } \\
\text { 3/п }\end{array}$ & МНН & Ефективність фармакотерапії & $\begin{array}{c}\text { Дозування та курс } \\
\text { лікування }\end{array}$ \\
\hline \multicolumn{3}{|c|}{ ДО } \\
\hline 1 & Амітриптилін & $\begin{array}{c}\text { побічні реакції (порушення } \\
\text { акомодації, слабкість, } \\
\text { запаморочення, тахікардія, } \\
\text { затримка сечовипускання, атонічні }\end{array}$ & $\begin{array}{c}25-100 \text { мг/день } \\
21-56 \text { днів }\end{array}$ \\
\hline
\end{tabular}


SSP Modern Pharmacy and Medicine (ISSN 2733-368X), Volume 1 Issue 2, Oct-Dec 2021

\begin{tabular}{|c|c|c|c|}
\hline & & $\begin{array}{c}\text { запори, сухість слизових) можуть } \\
\text { спровокувати розвиток } \\
\text { алкогольного делірію }\end{array}$ & \\
\hline 2 & $\begin{array}{l}\text { Тіанептин } \\
\text { (коаксил) }\end{array}$ & $\begin{array}{c}\text { при порушенні дозування та курсу } \\
\text { лікування і за наявності } \\
\text { індивідуальних протипоказань } \\
\text { можливий розвиток коаксилової } \\
\text { залежності з тяжкими фізичними, } \\
\text { психічними та поведінковими } \\
\text { розладами }\end{array}$ & $\begin{array}{c}\text { 37,5 мг/день } \\
\text { 20-30 днів }\end{array}$ \\
\hline \multicolumn{4}{|c|}{ ПІСЛЯ } \\
\hline 3 & Сертралін & $\begin{array}{l}\text { швидкий купіруючий вплив } \\
\text { депресивної симптоматики, } \\
\text { відсутність ускладнень }\end{array}$ & $\begin{array}{c}\text { 25-50 мг/день } \\
\text { 5-10 днів }\end{array}$ \\
\hline \multicolumn{4}{|c|}{ ВИСНОВОК } \\
\hline \multicolumn{4}{|c|}{$\begin{array}{l}\text { Запропонована схема фармакотерапії із включенням Л3 за МНН «Сертралін» } \\
\text { дала змогу підвищити ефективність лікувального процесу, зменшити } \\
\text { дозування (у 1,5-2 рази), скоротити терміни лікування (у 3-5 разів) }\end{array}$} \\
\hline
\end{tabular}

Враховуючи вище приведені дані, в анкети респондентів було включено антидепресанти за МНH «Амітриптилін», «Сертралін», «Тіанептин» для подальшого комплексного дослідження їх доступності для пацієнтів та медперсоналу.

Клініко-фармакологічне дослідження.

Проведено дослідження клініко-фармакологічної групи антидепресантів типу серліфт за МНН «Сертралін». Клініко-фармакологічна група препаратів із МНH «Сертралін» за класифікаційною системою АТС має АТC-код N06А В06.

Лікарі в анкетах вказали, що включали ЛЗ за МНН «Сертралін» у комплексну фармакотерапію психічних та наркологічних розладів (депресія, А3), зокрема серліфт. Антидепресанти на основі сертраліну добре переносяться пацієнтами та при правильно підібраному дозуванні майже не викликають побічних ефектів. Сертралін відноситься до селективних інгібіторів зворотнього нейронального захвату серотоніну; не виявляє стимулюючу, седативну, антихолінергічну та кардіотоксичну дію. Позитивною властивістю сертраліну $\epsilon$ практична відсутність холінолітичних ефектів, що дозволяє призначати препарат на ранніх етапах фармакотерапії. Серліфту також притаманна перевага власне антидепресивної і анксіолітичної дії. Добові дози серліфту при депресивних розладах знаходяться в межах 0,05-0,2 г. Разом 3 тим, серліфт при порівняно тривалій фармакотерапії може викликати серотоніновий синдром, нудоту, ознаки передозування препарату, тремор, пітливість, надлишкову седацію, порушення сну, алергічні реакції. Прийом серліфту в літньому віці може викликати розвиток синдрому неадекватної секреції антидіуретичного гормону. У літературі є повідомлення про те, що після тривалої фармакотерапії ЛЗ за МНН «Сертралін» і раптового припинення прийому, може виникнути своєрідний 
синдром відміни, що виявляється підвищенням тривоги, нервозністю, розладом сну, запамороченням.

Соціологічне дослідження (анонімне анкетування).

Наступним завданням дослідження стала оцінка доступності ЛЗ групи «Антидепресанти» за допомогою соціологічного методу анонімного анкетування респондентів за 3-х бальною шкалою. Обробка результатів анкетування проводилася шляхом статистичного методу аналізу. Статистичний аналіз результатів дослідження доступності ЛЗ групи «Антидепресанти» проводили за допомогою програмного пакету Microsoft Office Excel 2007 за такою послідовністю:

кожному респонденту присвоювали $j$-тий номер $\left(Y_{1}, Y_{2}, Y_{3} \ldots Y_{j}\right)$;

кожному лікарському засобу присвоювали $i$-тий номер $\left(X_{1}, X_{2}, X_{3} \ldots X_{i}\right)$;

проводили ранжування отриманих оцінок у вигляді матриці рангів;

розраховували суму оцінок респондентів $\left(\sum_{i=1}^{n} a_{i j}\right)$, суму рангів $\left(\sum_{i=1}^{n} \sum_{j=1}^{m} a_{i j}\right)$;

розраховували середньозважений ранг $\left(\bar{Z}_{i j}\right)$ за формулою:

$$
\bar{Z}_{i j}=\frac{K_{1} Z_{1}+K_{2} Z_{2}+\ldots+K_{i} Z_{i}}{K_{1}+K_{2}+\ldots+K_{1}}
$$

де $K$ - частота рангу;

узгодженість оцінювання доступності Л3 із групи «Антидепресанти» оцінювали за допомогою коефіцієнта конкордації Кендалла $(W)$, який розраховували за формулою:

$$
W=\frac{12 S}{m^{2}\left(n^{3}-n\right)}=\frac{12}{m^{2}\left(n^{3}-n\right)}\left[\sum_{j=1}^{m}\left(\sum_{i=1}^{n} a_{i j}-\frac{\sum_{j=1}^{m} \sum_{i=1}^{n} a_{i j}}{n}\right)^{2}\right],
$$

де $S$ - сума квадратів відхилення всіх рангів кожного чинника від середнього рангу;

$a_{i j}$ - ранг $i$-того ЛЗ у $j$-того респондента;

$m$ - кількість респондентів;

$n$ - кількість ЛЗ.

Якщо значення коефіцієнта конкордації Кендалла $(W)$ прагнуло до одиниці i становило більше ніж 0,8, то вважали отримані оцінки доступності ЛЗ групи «Антидепресанти» узгодженими між собою.

Для оцінки значущості коефіцієнтів конкордації Кендалла розраховувався критерій $\chi^{2}$ (критерій Пірсона) за наступною формулою:

$$
\chi^{2}=m(n-1) W=\frac{S}{\frac{1}{12} \min (n+1)},
$$

де $m$ - кількість респондентів;

$n$ - кількість Л3;

$W$ - коефіцієнт конкордації Кендалла; 
$S$ - сума квадратів відхилення всіх рангів кожного ЛЗ від середньозваженого рангу.

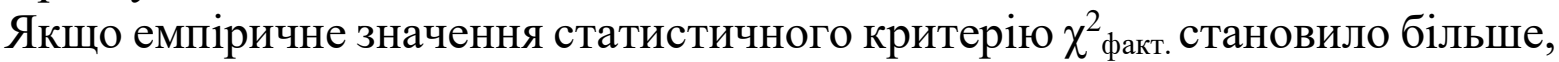
ніж табличне значення $\chi^{2}$ табл., то ранговий множинний зв'язок (узгодженість оцінок респондентів) вважали невипадковим і значущим.

Для визначення найбільш доступного антидепресанту за результатами статистичного аналізу будували гістограми розподілу за рангами, на підставі яких і відбирали найбільш перспективний ЛЗ із групи «Антидепресанти».

Респондентам був запропонований перелік відібраних ЛЗ 3 групи «Антидепресанти», які приведено у табл. 2.

Таблиця 2. Перелік лікарських засобів із групи «Антидепресанти».

\begin{tabular}{|c|l|l|}
\hline № 3/п & \multicolumn{1}{|c|}{$\begin{array}{c}\text { Міжнародна } \\
\text { непатентована назва }\end{array}$} & \multicolumn{1}{c|}{ Лікарська форма } \\
\hline 1 & Амітриптилін & таблетки по 25 мг N. 20 \\
\hline 2 & Тіанептин & таблетки по 12,5 мг N. 30 \\
\hline 3 & Сертралін & капсули по 50 мг або 100 мг N.28 \\
\hline
\end{tabular}

Отже, за допомогою методу анкетування респондентів 3 подальшим статистичним аналізом отриманих результатів за наведеною вище методикою спочатку досліджували доступність ЛЗ групи «Антидепресанти» шляхом оцінки вказаних критеріїв за 3-х бальною шкалою.

Так, за результатами анкетування респондентів щодо визначення доступності ЛЗ групи «Антидепресанти» отримано результати, що наведені у табл. 3.

Таблиця 3. Результати анкетування фахівців медицини щодо визначення доступності лікарських засобів групи «Антидепресанти».

\begin{tabular}{|c|c|c|c|}
\hline \multirow{2}{*}{$\begin{array}{c}\text { Оцінювання, } \\
\text { бали }\end{array}$} & \multicolumn{3}{|c|}{ Лікарські засоби групи «Антидепресанти» } \\
\cline { 2 - 4 } & Амітриптилін & Тіанептин & Сертралін \\
\hline 1 & 54 & 1 & 2 \\
\hline 2 & 1 & 55 & 1 \\
\hline 3 & 2 & 1 & 54 \\
\hline
\end{tabular}

За даними табл. 3 видно, що найвищим балом (3 бали) респонденти (54 особи) оцінили ЛЗ за МНН «Сертралін», а найнижчим (1 бал) - ЛЗ за МНН «Амітриптилін» (54 особи).

В результаті проведення статистичного аналізу були отримані проміжні дані, що приведені у табл. 4.

Розраховані для даного випадку коефіцієнт конкордації Кендалла $(W)$ та $\chi^{2}$-критерію відповідно дорівнюють 0,832 і 94,877. Високий рівень одержаних показників дозволив побудувати гістограми розподілу оцінок профілю безпеки за рангами, яка представлена на рис. 2. 
Таблиця 4. Проміжні дані первинного статистичного аналізу оцінок фахівців медицини щодо доступності лікарських засобів групи «Антидепресанти».

\begin{tabular}{|c|c|c|c|}
\hline \multirow{2}{*}{$\begin{array}{c}\text { Кількість } \\
\text { респондентів та } \\
\text { статистичні } \\
\text { показники їх оцінок }\end{array}$} & \multicolumn{3}{|c|}{ Лікарські засоби } \\
\hline & $\begin{array}{c}\text { Амітриптилін } \\
\left(\mathbf{X}_{1}\right)\end{array}$ & $\begin{array}{c}\text { Тіанептин } \\
\left(\mathrm{X}_{2}\right)\end{array}$ & $\begin{array}{c}\text { Сертралін } \\
\left(\mathbf{X}_{3}\right)\end{array}$ \\
\hline \multicolumn{4}{|l|}{$\mathrm{m}=57$} \\
\hline$\sum_{i=1}^{n} a_{i j}$ & 6 & 6 & 6 \\
\hline$\sum_{i=1}^{n} \sum_{j=1}^{m} a_{i j}$ & 62 & 114 & 166 \\
\hline $\bar{Z}_{i j}$ & 1,09 & 2,00 & 2,91 \\
\hline Ранг $Z_{j}$ & 3 & 2 & 1 \\
\hline
\end{tabular}

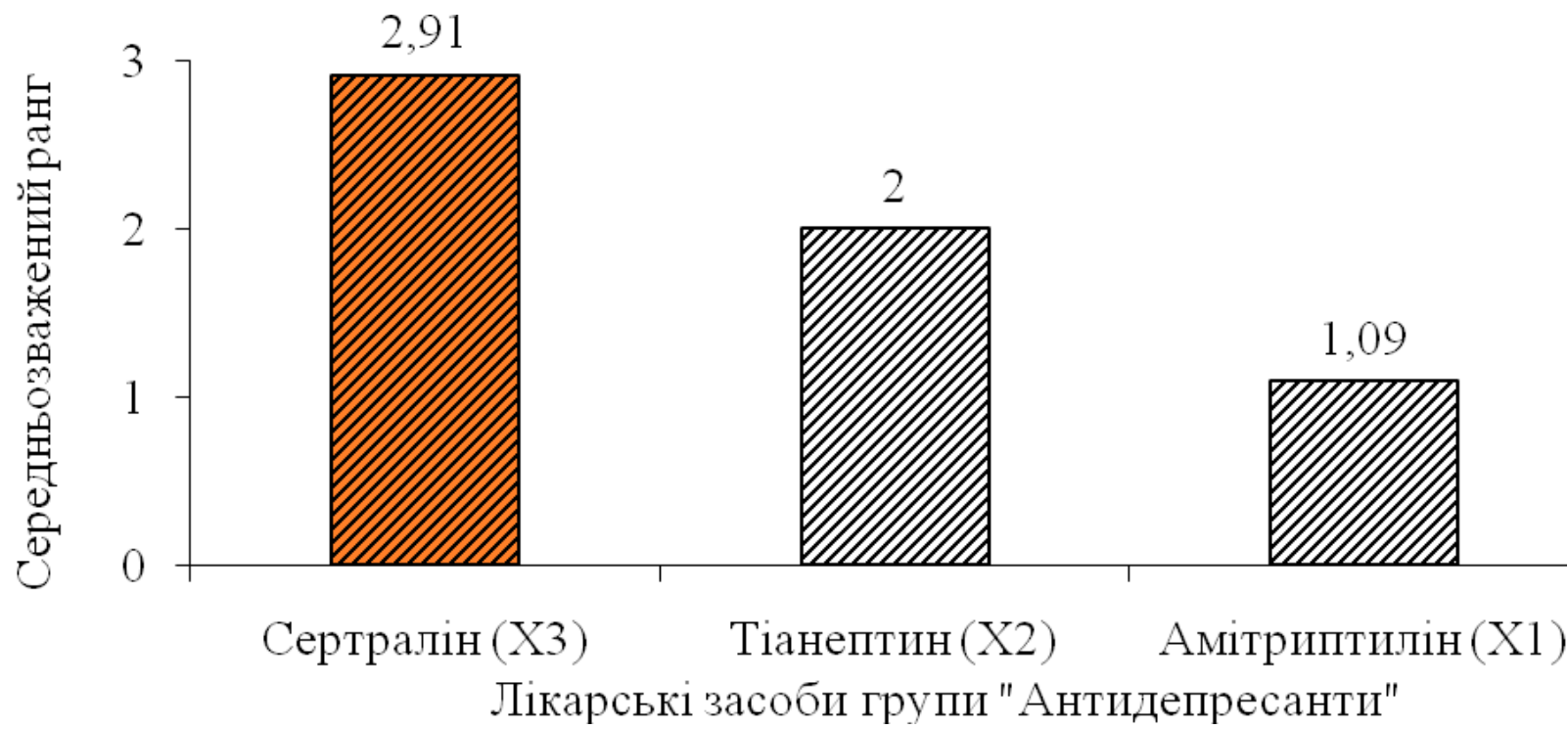

Рис. 2. Гістограма розподілу за рангами оцінок доступності лікарських засобів групи «Антидепресанти» спеціалістами медицини.

Отримані дані вказують на те, що більш доступним серед антидепресантів $\epsilon$ ЛЗ за МНН «Сертралін» $\left(\mathrm{X}_{3}\right)-2,91$.

Оцінювання доступності ЛЗ групи «Антидепресанти» фахівцями фармації приведено у табл. 5.

Таблиця 5. Результати анкетування фахівців фармації щодо доступності лікарських засобів групи «Антидепресанти».

\begin{tabular}{|c|c|c|c|}
\hline \multirow{2}{*}{$\begin{array}{c}\text { Оцінювання, } \\
\text { бали }\end{array}$} & \multicolumn{3}{|c|}{ Лікарські засоби групи «Антидепресанти» } \\
\cline { 2 - 4 } & Амітриптилін & Тіанептин & Сертралін \\
\hline 1 & 124 & 2 & 4 \\
\hline 2 & 3 & 125 & 2 \\
\hline 3 & 3 & 3 & 124 \\
\hline
\end{tabular}


Встановлено, що найбільша кількість респондентів (124 особи) оцінили ЛЗ за МНH «Сертралін» у 3 бали. Слід зазначити, що така ж кількість фахівців медицини оцінили доступність ЛЗ за МНН «Амітриптилін» у 1 бал.

Для підтвердження статистичної значущості отриманих результатів проведено їх аналіз за наведеною вище методикою. Проміжні дані статистичного аналізу оцінок доступності ЛЗ групи «Антидепресанти» приведені у табл. 6.

Таблиця 6. Проміжні дані первинного статистичного аналізу оцінок фахівців фармації щодо доступності лікарських засобів групи «Антидепресанти».

\begin{tabular}{|c|c|c|c|}
\hline \multirow{2}{*}{$\begin{array}{c}\text { Кількість } \\
\text { респондентів та } \\
\text { статистичні } \\
\text { показники їх оцінок }\end{array}$} & \multicolumn{3}{|c|}{ Лікарські засоби } \\
\hline & $\begin{array}{c}\text { Амітриптилін } \\
\left(\mathbf{X}_{1}\right)\end{array}$ & $\begin{array}{c}\text { Тіанептин } \\
\left(\mathbf{X}_{2}\right)\end{array}$ & $\begin{array}{c}\text { Сертралін } \\
\left(\mathrm{X}_{3}\right)\end{array}$ \\
\hline \multicolumn{4}{|l|}{$\mathrm{m}=130$} \\
\hline$\sum_{i=1}^{n} a_{i j}$ & 6 & 6 & 6 \\
\hline$\sum_{i=1}^{n} \sum_{j=1}^{m} a_{i j}$ & 139 & 261 & 380 \\
\hline$\overline{\bar{Z}}_{i j}$ & 1,07 & 2,01 & 2,92 \\
\hline Ранг $Z_{j}$ & 3 & 2 & 1 \\
\hline
\end{tabular}

Розрахунок значущого коефіцієнту конкордації $(W=0,859)$ та $\chi^{2}$-критерію $(223,40)$ дало можливість на підставі розрахованих середньозважених рангів оцінки доступності побудувати гістограму розподілу, що представлена на рис. 3.

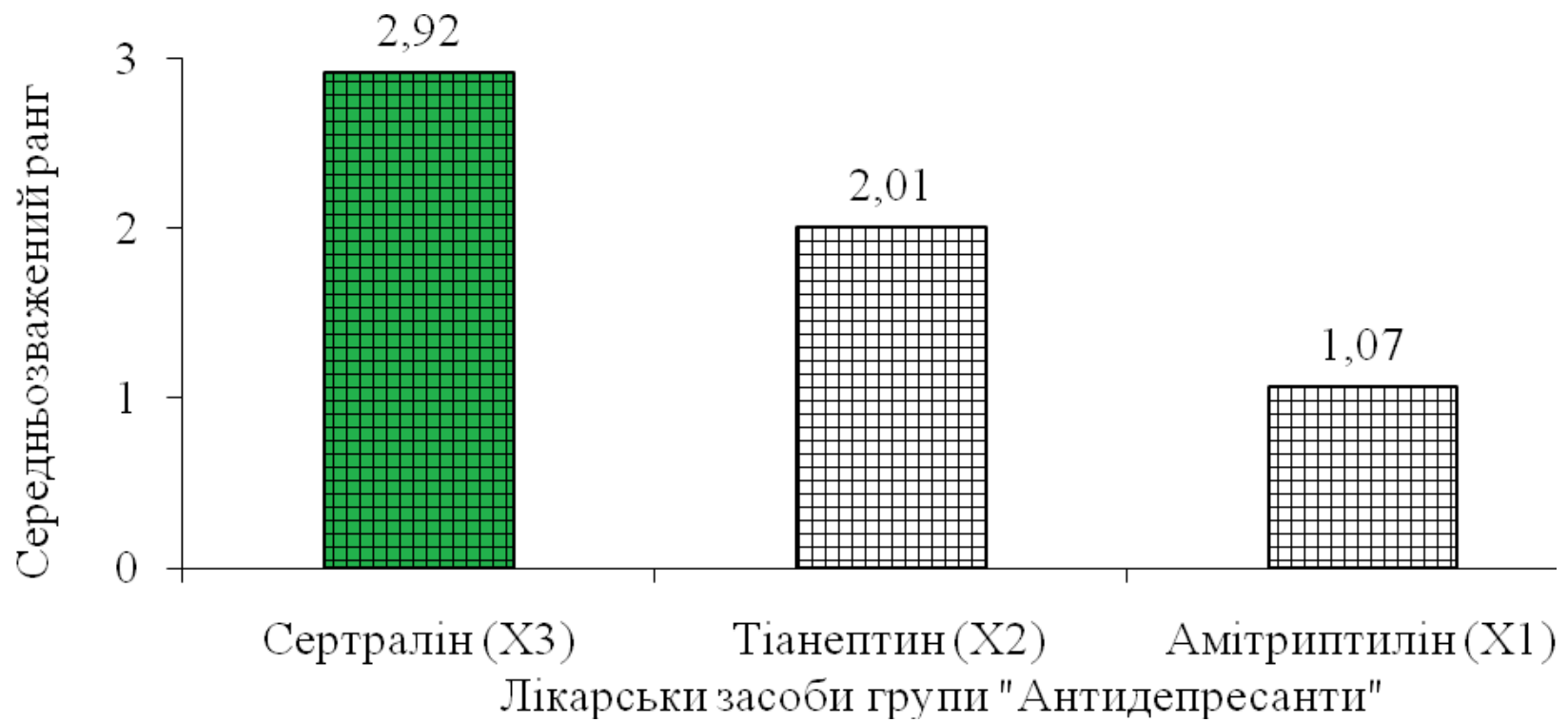

Рис. 3. Гістограма розподілу за рангами оцінок доступності лікарських засобів групи «Антидепресанти» спеціалістами фармації.

Із рис. 3 видно, що найбільш доступним за оцінками фахівців фармації $\mathrm{\epsilon}$ ЛЗ за МНH «Сертралін» $\left(\mathrm{X}_{3}\right)$, які отримали найвищий ранг $(2,92)$. 
За результатами аналізу анкетування двох контингентів респондентів (лікарів та провізорів) побудовано порівняльну гістограму розподілу за рангами оцінок доступності ЛЗ групи «Антидепресанти» (рис. 4).

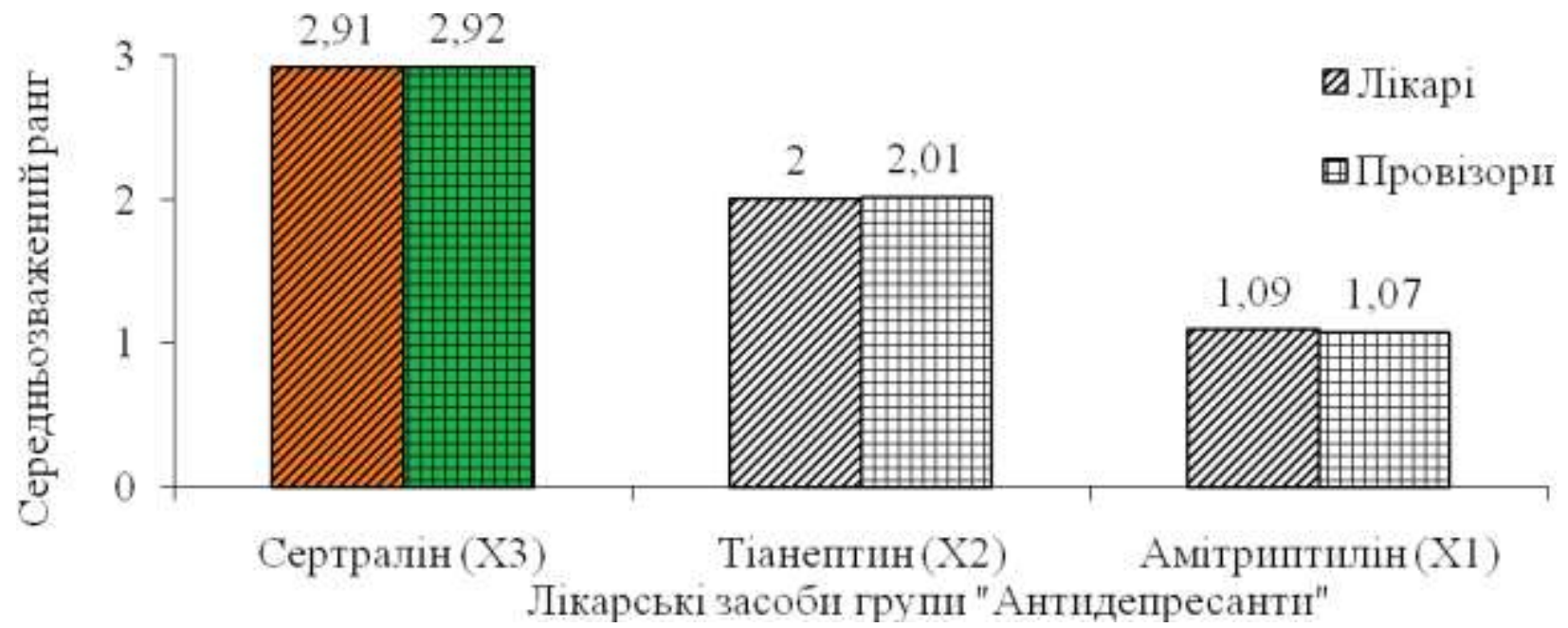

Рис. 4. Порівняльна гістограма і полігон розподілу за рангами оцінок доступності лікарських засобів групи «Антидепресанти» спеціалістами медицини і фармації.

Із рис. 4 видно, що середньозважені експертні оцінки доступності ЛЗ групи «Антидепресанти», надані респондентами медицини і фармації, майже однакові. Зокрема, найбільш доступним за оцінками лікарів і провізорів $є$ ЛЗ за МНH «Сертралін» $\left(\mathrm{X}_{3}\right)$, який отримав найвищий ранг (2,91 і 2,92 відповідно).

Отже, респондентами доступність ЛЗ за МНН «Сертралін» оцінена в стаціонарних умовах як сприятлива, а в умовах амбулаторного лікування депресивних розладів - оптимальна. Подальші дослідження проводилися тільки для ЛЗ за МНН «Сертралін».

Маркетингове дослідження.

Наступне завдання було дослідження торгових назв, країн виробників, термінів дії реєстраційних посвідчень, лікарських форм ЛЗ за МНН «Сертралін».

Встановлено, що ЛЗ за МНН «Сертралін» знаходяться в обігу на фармацевтичному ринку України закордонного та вітчизняного виробництва (Табл. 7).

Таблиця 7. Лікарські засоби за МНН «Сертралін».

\begin{tabular}{|c|c|c|c|}
\hline № $3 /$ П & $\mathrm{MHH}$ & Торгова назва & Країна виробник \\
\hline 1 & 2 & 3 & 4 \\
\hline 1 & \multirow{6}{*}{ Сертралін } & А-депресин & Teva (Ізраїль) \\
\hline 2 & & Адьювін & $\begin{array}{l}\text { Lannacher Helimittel } \\
\text { (Австрія) }\end{array}$ \\
\hline 3 & & Асентра & KRKA (Словаччина) \\
\hline 4 & & Депралін & Polpharma (Польща) \\
\hline 5 & & Залокс & Pharmascience (Канада) \\
\hline 6 & & Золофт & Pfizer Inc. (США) \\
\hline
\end{tabular}


SSP Modern Pharmacy and Medicine (ISSN 2733-368X), Volume 1 Issue 2, Oct-Dec 2021

\begin{tabular}{|c|c|c|}
\hline 7 & Серліфт & Ranbaxy (Індія) \\
\hline 8 & Сертралін-Апо & Apotex (Канада) \\
\hline 9 & Сертралофт & ТОВ «Здоров’я» (Україна) \\
\hline 10 & Сертралюкс & Sandoz (Словаччина) \\
\hline 11 & Солотик & Hikma (Іорданія) \\
\hline 12 & Стимулотон & Egis (Угорщина) \\
\hline 13 & $\begin{array}{l}\text { Дебітум - } \\
\text { Сановель }\end{array}$ & Turkey (Туреччина) \\
\hline 14 & Емотон & Portugal (Португалія) \\
\hline
\end{tabular}

Як видно із табл. 7, в обігу на фармацевтичному ринку України знаходиться переважно ЛЗ за МНН «Сертралін» закордонного виробництва $(92,8 \%)$.

Аналіз даних щодо реєстрації ЛЗ за МНН «Сертралін» на території України приведено в табл. 8.

Таблиця 8. Дані щодо реєстрації лікарських засобів за МНН «Сертралін»на території України.

\begin{tabular}{|c|c|c|c|c|}
\hline \multirow{2}{*}{$\begin{array}{l}\text { № } \\
\text { 3/п }\end{array}$} & \multirow{2}{*}{$\begin{array}{c}\text { Торгова } \\
\text { назва }\end{array}$} & \multirow{2}{*}{$\begin{array}{c}\text { Номер реєстраційного } \\
\text { посвідчення }\end{array}$} & \multicolumn{2}{|c|}{$\begin{array}{c}\text { Термін дії реєстраційного } \\
\text { посвідчення }\end{array}$} \\
\hline & & & $\begin{array}{c}\text { дата початку, } \\
\text { p. }\end{array}$ & $\begin{array}{c}\text { дата закінчення, } \\
\text { p. }\end{array}$ \\
\hline 1 & 2 & 3 & 4 & 5 \\
\hline 1 & А-депресин & UA/9464/01/01 & 24.03 .2009 & 24.03 .2014 \\
\hline 2 & Адьювін & UA/9522/01/01 & 08.04 .2009 & 08.04 .2014 \\
\hline 3 & Асентра & UA/8770/01/01 & 16.08 .2018 & необмежений \\
\hline 4 & $\begin{array}{l}\text { Дебітум - } \\
\text { Сановель }\end{array}$ & UA/12668/01/01 & 11.01 .2019 & 11.01 .2024 \\
\hline 5 & Депралін & UA/9024/01/01 & 22.10 .2008 & 22.10 .2013 \\
\hline 6 & Емотон & UA/15643/01/01 & 02.07 .2021 & необмежений \\
\hline 7 & Залокс & UA/8205/01/01 & 22.10 .2018 & необмежений \\
\hline 8 & Золофт & $\mathrm{UA} / 7475 / 01 / 01$ & 13.12 .2017 & необмежений \\
\hline 9 & Серліфт & UA/4446/01/01 & 06.04 .2017 & необмежений \\
\hline 10 & $\begin{array}{c}\text { Сертралін- } \\
\text { Апо }\end{array}$ & UA/9834/01/01 & 07.07.2008 & 07.07 .2014 \\
\hline 11 & Сертралофт & UA/8406/01/01 & 19.03.2018 & необмежений \\
\hline 12 & Сертралюкс & UA/6933/01/02 & 17.08 .2007 & 17.08 .2012 \\
\hline 13 & Солотик & UA/8844/01/02 & 26.08.2008 & 26.08 .2013 \\
\hline 14 & Стимулотон & UA/3195/01/01 & 23.10 .2020 & 23.10 .2025 \\
\hline
\end{tabular}

Слід вказати, що на території України деякі Л3 за МНН «Сертралін» не продовжили свою реєстрацію і були виключені із обігу (А-депресин, Адьювін, Депралін, Сертралін-Апо, Сертралюкс, Солотик). ЛЗ за МНН «Сертралін», що залишилися, мають необмежений термін реєстрації та дозволені до медичного застосування на території України. 
ЛЗ за МНН «Сертралін» випускаються у двох лікарських формах (капсули та таблетки), а також у трьох дозировках (25 мг, 50 мг та 100 мг), що на прикладі ЛЗ залокс, золофт і сертралін-Апо приведено у табл. 9.

Таблиця 9. Лікарські форми та дозування ЛЗ за МНН «Сертралін».

\begin{tabular}{|c|c|c|c|}
\hline МНH & Торгова назва & \multicolumn{2}{|c|}{ Лікарська форма } \\
\hline \multirow{3}{*}{ Сертралін } & Залокс & Таблетки & 25 мг N. 10 \\
\cline { 2 - 4 } & Золофт & Таблетки & 50 мг N. 28 \\
\cline { 2 - 4 } & Сертралін-Апо & Капсули & 100 мг N. 28 \\
\hline
\end{tabular}

Класифікаиійно-правове дослідження.

Класифікаційно-правова група ЛЗ за МНH «Сертралін» визначалася за допомогою нормативно-правового та документального методів аналізу.

3’ясовано, що ЛЗ за МНН «Сертралін» не входить до переліків: наркотичних засобів, психотропних речовин, прекурсорів, сильнодіючих ЛЗ, отруйних ЛЗ, радіоактивних речовин, засобів допінгу, легкозаймистих, їдких, вибухових речовин, засобів гомеопатії відповідно до Постанови Кабінету Міністрів України від 06.05.2000 р. №770 «Про затвердження Переліку наркотичних засобів, психотропних речовин і прекурсорів» та наказу МОЗ України від 17.08.2007 p. № 490 «Про затвердження Переліків отруйних та сильнодіючих лікарських засобів» [27-29].

Отже, ЛЗ за МНН «Сертралін» за класифікаційно-правовою ознакою віднесено до «загальної групи».

Номенклатурно-правове дослідження.

Номенклатурно-правова група ЛЗ за МНН «Сертралін» визначалася шляхом нормативно-правового та документального методів аналізу.

Слід відмітити, що ЛЗ за МНН «Сертралін» відсутні у наказі МОЗ України «Про затвердження переліку лікарських засобів, дозволених до застосування в Україні, які відпускаються без рецептів з аптек та їх структурних підрозділів» від 18.04.2019 p. №876.

Номенклатурно-правова група ЛЗ за МНН «Сертралін» визначалася за наказом MO3 України від 19.07.2005 р. №360 «Про затвердження Правил виписування рецептів та вимог-замовлень на лікарські засоби і вироби медичного призначення, Порядку відпуску лікарських засобів і виробів медичного призначення 3 аптек та їх структурних підрозділів, інструкції про порядок зберігання, обліку та знищення рецептурних бланків та вимогзамовлень» $[30,31]$.

Встановлено, що ЛЗ за МНН «Сертралін» відносяться до рецептурної номенклатурно-правової групи, відпускаються із аптек та їх структурних підрозділів за багаторазовим рецептом $\Phi-1$ i не підлягають предметнокількісному обліку.

Отже, формула режиму контролю ЛЗ за МНH «Сертралін» має такий вигляд:

РК ЛЗ за МНH «Сертралін» = N06АВ06 + Загальна група + Багаторазовий рецепт Ф-1 
Останнє дає підставу зробити висновок, що за судово-фармацевтичним критерієм «режим контролю» ЛЗ за МНН «Сертралін» $\epsilon$ доступними для постраждалих контингентів пацієнтів та їх близьких родичів 3 різним рівнем достатку.

Використання ЛЗ за МНH «Сертралін» буде реалізувати соціально орієнтовані підходи у фармакотерапії, що вкрай важливо для такого контингенту пацієнтів як постраждалі особи в умовах особливого періоду в Україні.

Висновки. Досліджено доступність ЛЗ за МНН «Сертралін», «Тіанептин», «Амітриптилін» $з$ використанням комплексного підходу. Обгрунтовано, що ЛЗ за МНH «Сертралін» є найбільш доступними для медперсоналу та постраждалих контингентів пацієнтів. Визначено особливості клініко-фармакологічної, класифікаційно-правової та номенклатурно-правової груп ЛЗ за МНH «Сертралін». Зазначено, що використання ЛЗ за МНH «Сертралін» буде відповідати принципам соціально орієнтованої фармакотерапії психічних розладів для постраждалих контингентів пацієнтів в умовах особливого періоду в Україні.

Подяки. Автор висловлює вдячність кафедрі медичного та фармацевтичного права, загальної і клінічної фармації (завідувачка - проф. Шаповалова В.О.) Харківської медичної академії післядипломної освіти за сприяння та допомогу у проведенні дослідження.

\section{Література.}

1. V. Shapovalov (Jr.), A. Gudzenko, L. Komar et al. Concerning the importance of forensic and pharmaceutical researches to improve patients' accessibility to medicines. Pharmacia. 2017. Vol. 65, № 2. P. 23-29.

2. V.A. Shapovalova, S.I. Zbrozhek, V.V. Shapovalov et al. Forensic pharmacy: some risk factors in the formation of addictive health disorders. Acta Scientific Pharmaceutical Science. 2021. Vol. 4. Iss. 1. P. 7-12. DOI: 10.3180/ASPS.2020.05.0651.

3. V.O. Shapovalova, S.I. Zbrozhek, V.V. Shapovalov et al. Forensic and pharmaceutical study of causal relationships between social and medical risk factors in the formation of addictive health disorders/ Health of society. 2020. T.9. №6. P. 236242. DOI: https://doi.org/10.22141/2306-2436.9.6.2020.226954.

4. Shapovalov V.V., Shapovalov V.V. (Jr.), Shapovalova V.O. et al. The study of interdisciplinary connections of criminal law and forensic pharmacy in the system turnover of medical drugs. Theory and practice of jurisprudence. 2017. 1(11). P. 1-9. URL: http://tlaw.nlu.edu.ua/article/view/94316. DOI: http://doi.org/10.21564/2225$\underline{6555.2017 .11 .94316 .}$

5. Shapovalov V.V. Sudovo-farmatsevtychne vyvchennia problemy zlovzhyvannia ta vidpratsiuvannia pravovykh pryntsypiv skorochennia popytu na psykhoaktyvni rechovyny riznykh klasyfikatsiino-pravovykh hrup. Farmatsevtychnyi zhurnal. 2014. № 2. S. 39-47.

6. Shapovalov V. (Jr.), Gudzenko A., Shapovalova V. Et al. Forensic and pharmaceutical study of the presence of a causal link between the degree of alcohol 
abuse and qualification level of the respondents Pharmacia. 2017. Vol. 66. N. 3. P. 3139. URL: http://bsphs.org/wp-content/uploads/2017/11/Shapovalov.pdf.

7. Shapovalov V.V., Shapovalova V.A., Shapovalov V.V. (Jr. ) et al. The problem of turnover of the psychoactive substance alcohol: abuse, consequences, countermeasures. Research result (Medicine and Pharmacy Series). 2014. Vol. 1. N. 2 (2). P. 45-51. URL: http://rr.bsu.edu.ru/images/issue2/pharmacy/selection\%20(6).pdf. 8. Shapovalova V.A., Datkhayev U.M., Shapovalov V.V. (Jr.) et al. Introduction to pharmaceutical law and forensic pharmacy. The Third International scientific congress of scientists of Europe: Proceedings of the III International Scientific Forum of Scientists "East-West" (January 11, 2019). Premier Publishing s.r.o. Vienna. 2019. P. 43-49.

9. Shapovalov V.V., Gudzenko A.A., Shapovalova V.A. et al. Forensic and pharmaceutical analysis of addictive morbidity because of the use of psychoactive substances in Ukraine. Klin. inform. telemed. 2020. Vol. 15. Iss. 16. P. 125-128. URL: https://doi.org/10.31071/kit2020.16.02.

10. Shapovalova V., Shapovalov V., Negretsky S. Forensic and pharmaceutical problems concerning circulation of cannabis: perspectives of state control, medical and narcological health effects. Actual problem of medicine and pharmacy. 2020. Vol. 1 No. 1-2. URL: http://apmplmi.com.

11. Narkolohiia: Natsionalnyi pidruchnyk : Za redaktsiieiu prof. I.K. Sosina, dots. Yu.F. Chuieva. Kharkiv : Kolehium, 2014. 1500 s.

12. Pro psykhiatrychnu dopomohu. Zakon Ukrainy vid 22 liutoho 2000 r. N 1489III. URL: http://zakon.rada.gov.ua/laws/show/1489-14.

13. Chuiev Y., Shapovalova V. Interdisciplinary Pharmacoeconomic Study of Pharmacotherapy of Cupping of Drunk Forms of Alcohol Dependence: Clinical and Pharmacological, Organizational, Legal and Marketing Experiment. SSP Modern Pharmacy and Medicine. 2021. Vol. 1. N. 2. P. 1-12. URL: https://doi.org/10.53933/sspmpm.v1i2.24.

14. Gudzenko A., Shapovalov V., Shapovalov V. et al. Forensic pharmacy: analysis of complaints about the pharmaceutical provision for privileged categories of patients in Ukraine (experimental research). Science Review. 2021. Vol. 2. Iss. 37. P. 1-6. DOI: https://doi.org/10.31435/rsglbal_sr/30042021/7517.

15. V.O. Shapovalova, S.I. Zbrozhek, V.V. Shapovalov et al. Coronavirus disease pandemia 2019: growth of epidemic dangers. Acta scientific pharmaceutical sciences. 2020. Vol. 4. Iss. 7. P. $61-68$.

16. Shapovalov V., Butko L., Shapovalov V. Organizational and Legal Study of Quarantine Restrictions in The Spread of Coronavirus Disease in Ukraine. SSP Modern Pharmacy and Medicine. 2021. Vol. 1. N. 2. P. 1-12. URL: https://doi.org/10.53933/sspmpm.v1i2.23.

17. Zbrozhek S.I. Analiz dostupnosti obihu likarskykh zasobiv dlia riznykh kontynhentiv patsiientiv v zakladakh okhorony zdorovia. 2020. Likarska sprava. № 78. S. 56-63. doi: https://doi.org/10.31640/JVD.7-8.2020(7).

18. Shapovalov V.V. (Jr.), Gudzenko A.A., Andrieieva V.V. et al. Experience of the USA concerning and organization of healthcare system for the pharmaceutical 
provision for privileged categories of citizens. Annals of Mechnikov Institute. 2019. №1. P. 81-87. URL: http://www.imiamn.org.ua/journal/1_2019/PDF/13.pdf. DOI: 10.5281/zenodo.2639521.

19. V. Shapovalov (jr.), S. Zbrozhek, A. Gudzenko et al. Organizational and legal analysis of the pharmaceutical provision for the most common diseases of society I International Journal of Pharmaceutical Sciences Review and Research. 2018. Vol. 51. N. 1. P. 118-124. URL: http://globalresearchonline.net/journalcontents/v51$1 / 18 . p d f$.

20. Gudzenko A., Shapovalov V., Shapovalova V. et al. Organization and legal aspects of the use of marketing analysis of multivitamin complexes for pharmaceutical provision of health diseases among combatants. Acta scientific pharmaceutical sciences. 2021. Vol. 5. Iss. 4. P. 74 - 80. DOI: 10.31080/ASPS.2021.05.0704.

21. Shapovalov V.V., Shapovalova V.O., Andrieieva V.V. et al. Experience of Great Britain in organization of healthcare system for pharmaceutical provision with medicines for privileged categories of citizens. Health of society. 2019. Vol. 78, N. 1. P. 36-40. DOI: 10.22141/2306-2436.8.1.2019.172617.

22. V. Shapovalov (Jr.), A. Gudzneko, V. Shapovalova et al. Forensic and pharmaceutical analysis of addictive morbidity because of the use of narcotic psychoactive substances in Ukraine (retrospective aspect). International Journal of Pharmaceutical Sciences and Research. 2018. Vol. 3. Is. 3. P. 22-25. URL: http://www.pharmacyjournal.net/archives/2018/vol3/issue3.

23. Shapovalov V.V., Gudzenko A.A., Zbrozhek S.I. et al. Forensic and pharmaceutical analysis of addictive morbidity because of the use of psychotropic psychoactive substances in Ukraine (retrospective aspect). Annals of Mechnikov Institute. $2018 . \quad$ №3. $\quad$ P. $41-44 . \quad$ URL: http://www.imiamn.org.ua/journal/3_2018/PDF/9.pdf.

24. Shapovalov V. (Jr.), Gudzenko A., Shapovalov V. et al. Organizational, legal and marketing characteristics of domestic medicines for pharmaceutical provision to victims suffered from emergency situations in Ukraine. The Pharma Innovation Journal. 2018. Vol. 7. N. 6. P. 586-589. URL: http://www.thepharmajournal.com/archives/2018/vol7issue6/PartI/7-5-100-255.pdf.

25. Sposib intehrovanoho kupiruvannia depresyvnykh rozladiv pry alkoholnomu abstynentnomu syndromi: informatsiinyi lyst pro novovvedennia / I.K. Sosin, V.V. Shapovalov, V.O. Shapovalova, O.S. Slabunov, Yu.F. Chuiev, O. Yu.Honcharova, V.V. Shapovalov (ml.), I.M. Skvira, O. V. Peresypkin. Ust.-rozrobn.: KhMAPO MOZ Ukrainy, Ukrmedpatentinform MOZ Ukrainy. K.: Ukrmedpatentinform MOZ Ukrainy, 2012. - № 352-2012, vyp. 7. 4 s.

26. Rezhym kontroliu likarskykh zasobiv dlia farmakoterapii depresyvnoho epizodu ta rekurentnoi depresii (F 30-39): informatsiinyi lyst pro novovvedennia / Shapovalova V.O., Zbrozhek S.I., Hudzenko A.O., Shapovalov V.V., Shapovalov V.V. Ust.-rozrobn.: KhMAPO MOZ Ukrainy, Ukrmedpatentinform MOZ Ukrainy. K.: Ukrmedpatentinform MOZ Ukrainy, 2018. №109-2018, vyp. $1.8 \mathrm{~s}$.

27. Shapovalov V.V., Gudzenko A.A., Zbrozhek S.I. et al. Forensic and pharmaceutical analysis of addictive morbidity because of the use of psychotropic 
psychoactive substances in Ukraine (retrospective aspect). Annals of Mechnikov Institute. $2018 . \quad$ №3. $\quad$ P. http://www.imiamn.org.ua/journal/3_2018/PDF/9.pdf.

28. Zbrozhek S. (2021). Medical and pharmaceutical legislation: normative and legal regulation of healthcare specialists' activities in Finland. SSP Modern Pharmacy and Medicine. 2021. Vol. 1. No. 1. P. 1-8. URL: https://doi.org/10.53933/sspmpm.v1i1.5.

29. Gudzenko A. Pharmaceutical provision of affected individuals in conditions of special period. Actual Problems of Medicine and Pharmacy. 2021. Vol. 2. No. 1. P. 18. URL: https://doi.org/10.52914/apmp.v2i1.28.

30. Gudzenko A. (2021). Substantiation of components of the national list of medicines of domestic production for pharmaceutical provision of affected persons in conditions of the special period in Ukraine. SSP Modern Pharmacy and Medicine, 1(1), 1-6. https://doi.org/10.53933/sspmpm.v1i1.15.

31. Shapovalov V.V. (Jr.), Gudzenko A.O., Shapovalova V.A. et al. Experience of Poland concerning and organization of healthcare system for the pharmaceutical provision for privileged categories of citizens. Proceeding of articles, the international scientific conference "Advance of Science". Czech Republic, Karlovy Vary - Ukraine, Kyiv, 17 May 2019. Czech Republic, Karlovy Vary: Skleněný Můstek - Ukraine, Kyiv: MCNIP, 2019. P. 16-22. 